\title{
IMPROVED BIOLOGICAL IMAGE TRACKING ALGORITHM OF ATHLETE'S CERVICAL SPINE HEALTH
}

\author{
ALGORITMO APRIMORADO DE RASTREAMENTO DE IMAGENS BIOLÓGICAS DA SAÚDE DA COLUNA \\ CERVICAL DOATLETA
}

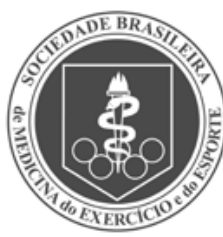

Original Article ARTIGO ORIGINAL Artículo Original

\section{ALGORITMO MEJORADO DE SEGUIMIENTO DE IMÁGENES BIOLÓGICAS DE LA SALUD DE LA COLUMNA CERVICAL DEL ATLETA}

\begin{abstract}
Chunmin Dai ${ }^{1}$ (D)
(Physical Education Professional)

Yang Lu ${ }^{1}$ (D)

(Physical Education Professional)

1. International Football Education school, Jilin Agricultural University, 2888 Xincheng Street, Changchun, China
\end{abstract}

\section{Correspondence}

Yang Lu

International Football Education school, Jilin Agricultural University, Changchun 130118, Jilin, China. luyangifes@yeah.net

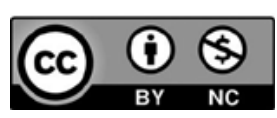

\begin{abstract}
Introduction: This paper research an improved biological image tracking algorithm of athlete's cervical spine health under color feedback. Objective: A new algorithm is proposed to improve the accuracy of detection and tracking. Methods: In this study, the first thing is to apply the color feedback algorithm to improve and optimize the Improved Camshift algorithm. The optimized algorithm was used to track the center of the image, and the video was processed frame by frame. The center position of the tracking frame was obtained. Results: The average number of head twists per person is 39 times. Among the three groups, children twisted the least, and older adults twisted the most. Conclusion: The algorithm proposed in this study has certain effectiveness and superiority and can be well applied to detecting the number of head twists during exercise. Level of evidence II; Therapeutic studies - investigation of treatment results.
\end{abstract}

Keywords: Spine, Biological Image, Algorithms.

\section{RESUMO}

Introdução: Este artigo investiga um algoritmo aprimorado para rastrear imagens biológicas da saúde da coluna cervical do atleta sob feedback de cores. Objetivo: Um novo algoritmo é proposto para melhorar a precisão de detecção e monitoramento. Métodos: neste estudo, primeiro aplicamos o algoritmo de feedback de cores para otimizar o algoritmo Camshift aprimorado. O algoritmo otimizado foi usado para rastrear o centro da imagem e 0 vídeo foi processado quadro a quadro. A posição central do quadro de rastreamento foi obtida. Resultados: o número médio de voltas da cabeça por pessoa é 39 vezes. Entre os três grupos, as crianças viraram menos e os adultos mais velhos viraram mais. Conclusão: O algoritmo proposto neste estudo tem alguma eficácia e superioridade e pode ser bem aplicado para detectar o número de giros da cabeça durante o exercício. Nível de evidência Il; Estudos terapêuticos: investigação dos resultados do tratamento.

Descritores: Coluna Vertebral, Imagens Biológicas, Algoritmos.

\section{RESUMEN}

Introducción: Este artículo investiga un algoritmo mejorado de seguimiento de imágenes biológicas de la salud de la columna cervical del atleta bajo retroalimentación de color. Objetivo: Se propone un nuevo algoritmo para mejorar la precisión de la detección y el seguimiento. Métodos: En este estudio, lo primero es aplicar el algoritmo de retroalimentación de color para optimizar el algoritmo Camshift mejorado. El algoritmo optimizado se utilizó para rastrear el centro de la imagen y el video se procesó cuadro por cuadro. Se obtuvo la posición central del marco de seguimiento. Resultados: El número medio de giros de cabeza por persona es 39 veces. Entre los tres grupos, los niños eran los que menos giraban y los adultos mayores eran los que más. Conclusión: El algoritmo propuesto en este estudio tiene cierta efectividad y superioridad y se puede aplicar bien para detectar el número de giros de cabeza durante el ejercicio. Nivel de evidencia ll; Estudios terapéuticos: investigación de los resultados del tratamiento.

Descriptores: Columna Vertebral, Imagen Biológica, Algoritmos.

\section{INTRODUCTION}

In recent years, the incidence of cervical spondylosis has been increasing. The emergence of such occupational factors may be related to some aspects, such as the increasing pressure of social competition, the shortening of people's time for daily activities, the long-time work or study, and the weak awareness of health care. ${ }^{1,2}$ These keep the neck muscles and ligaments in tension for a long time. If the cervical spine is diseased, the lighter cannot twist flexibly, and the serious can cause some diseases of other systems, such as arteriosclerosis, hypertension, coronary heart disease, and even paralysis. ${ }^{3}$ Therefore, how to effectively protect the health of the cervical spine has become a very important issue in modern life and work. Athletes are a special profession. According to research, taking table tennis players as an example, two legs must move 1000 to 2000 meters and swing the ball more than 1,000 
times so that all muscle groups in the whole body can be exercised. For the cervical spine, the neck will shake to the left and right along with the swing in table tennis. It is useful for the prevention and treatment of cervical spondylosis. ${ }^{4}$ The fatigue of the neck muscle group can be well relieved, and blood circulation around the neck can be promoted. Then cervical spondylosis can be effectively prevented and treated. ${ }^{5}$ To complete the subject,some researchers have proposed a mean shift algorithm to optimize the bandwidth automatic search strategy, and improved the manual mean shift algorithm to automatically find and optimize the bandwidth parameters. ${ }^{6}$ Others have proposed a mean shift tracking algorithm based on block color histograms, which mainly enables the algorithm to adapt to the rotation and scale changes of the target. ${ }^{7}$ In addition, they proposed a method of quadratic frame difference combined with tracking multiple feature targets to detect moving targets, which makes the detection effect better., ${ }^{8,9}$ This paper uses the color feedback algorithm to optimize and improve the Improved Camshift algorithm, to achieve accurate positioning and tracking of the center position of the target where the image is located. And the $\mathrm{ROI}$ (region of interest) of the video settings is optimized. Then, through experiments, the effectiveness of the proposed optimization algorithm is tested, and the acquired biological image of the video is enhanced by applying MVEF (Mean-Variance Efficient Frontier) algorithm. Finally, the experiment is conducted to verify the effectiveness of the algorithm proposed in this research. The results show that the improved algorithm can greatly increase the accuracy of positioning and tracking the center of the target where the image is located. According to the research, proper exercise has a great effect on relieving cervical spine diseases and has great value in restoring cervical spine health.

\section{METHODS}

\section{Improvement of Improved Camshift Algorithm under Color Feedback}

This research is mainly to improve and optimize the Improved Camshift algorithm to achieve the purpose of increasing tracking accuracy and reducing errors. This experiment is very special. To ensure that the red area in the video is unique, this research uses the color feedback to improve the Improved Camshift algorithm. By performing conditional feedback on it, the algorithm can be improved to achieve a closed loop to further increase the tracking accuracy. As shown in the figure 1 , it is the normal cervical vertebrae and the straightening of physiological curvature of cervical spine.

Through the space model of HSV (Hue Saturation Value) color, it is found that the distribution form of the $\mathrm{H}$ component is 360 degrees. Therefore, the 0 and 1 of the $\mathrm{H}$ components are the same. The purpose is to merge two discrete data into a continuous interval. Thus, a certain transformation of the $\mathrm{H}$ component value is needed. And then

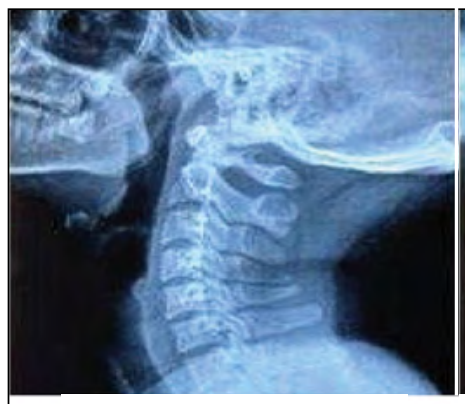

A - Noral cervical vertebrae

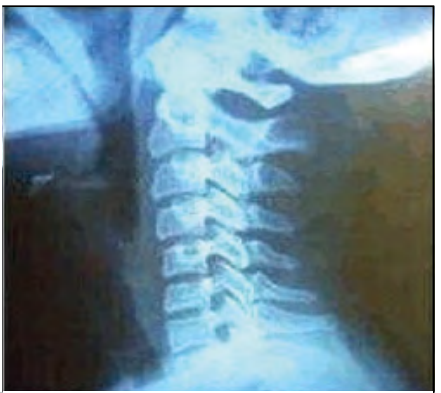

B - Straightening of physiological curvature of cervical spine
Figure 1. The normal cervical vertebrae and the straightening of physiological curvature of cervical spine. the interval of the $\mathrm{H}$ component value can be determined as $[0.2,0.6]$. The transformation equation is shown below.

$s(x, y)=T(r)=\left\{\begin{array}{c}r(x, y)+0.4,0 \leq r(x, y) \leq 0.2 \\ r(x, y)-0.6,0.8 \leq r(x, y) \leq 1.0\end{array}\right.$

Where: $s(x, y)$ represents the $\mathrm{H}$ component after transformation, and $r(x, y)$ represents the $\mathrm{H}$ component before transformation. To achieve the best tracking effect, the histogram of the image needs to be further transformed. The histogram can be further superimposed to find the smallest value. The equations are shown below.

$$
M=\min \left(\sum_{j=m}^{m+1} \operatorname{count}(i)\right), 0 \leq m \leq 255
$$

$$
i=\left\{\begin{array}{c}
i, \text { if } 0 \leq i \leq 255 \\
i-256, \text { if } i \geq 256
\end{array}\right.
$$

Where: count $(i)$ represents the value of the $\mathrm{H}$ component after normalization. The value of the $\mathrm{H}$ component is distributed in the interval $[0,1]$, and the minimum value is represented by $M$.

The main principle of color feedback is to expand the setting of the threshold by optimizing the $\mathrm{ROI}$ area of the video settings. After the setting is completed, the red pixels in the space are extracted and clustered. Through this method, the outline of the red pixel square and the position of the region can be obtained.

Based on the experimental data obtained through optimization and improvement using color feedback, the data can be applied to the Improved Camshift algorithm. The main process of the algorithm is shown in the figure 2 .

The first thing is to use the Camshift algorithm to start tracking and perform frame-by-frame processing on the video to get the center position of the tracking frame. And the video will extract the red pixels in the color space of each picture in real time. Then the distance between the two pixels of the picture is calculated. The two pixels are $\mathrm{O} 1$ and $\mathrm{O} 2$, and the distance is represented by length. If the distance value is smaller than the set threshold $\mathrm{M}$, it can be judged that there is no error in the tracked target. At this time, the pixel coordinate of $\mathrm{O} 1$ is used as the new search center coordinate, then the processing of the next image is started. If it is found that the distance value is larger than the set threshold, it is judged that there is an error in the tracked target. Therefore, the pixels around the two center points need to be re-determined. The number of red pixels can be determined according to the value of the red pixels in the RGB (Red Green Blue) color space. The most is recorded as $\mathrm{O} 3$ and the least is recorded as $\mathrm{O} 4$. The relationship between these pixels is shown below.

$$
O 1=0.8 * O 3+0.2 * O 4
$$

At this time, the distance between $\mathrm{O} 1$ and $\mathrm{O} 3$ needs to be calculated.

\section{Detection of the algorithm}

This study needs to detect the improved algorithm. First, the coordinates of the center pixel points of the three black squares are detected, as shown in Figure 4. Then, their coordinates are calculated. It is found that by connecting these three points, a triangle shape can be constructed, as shown in Figure 3. When the athlete twists his neck, the center coordinates of the black square will also change with the coordinates of the other two black squares. 


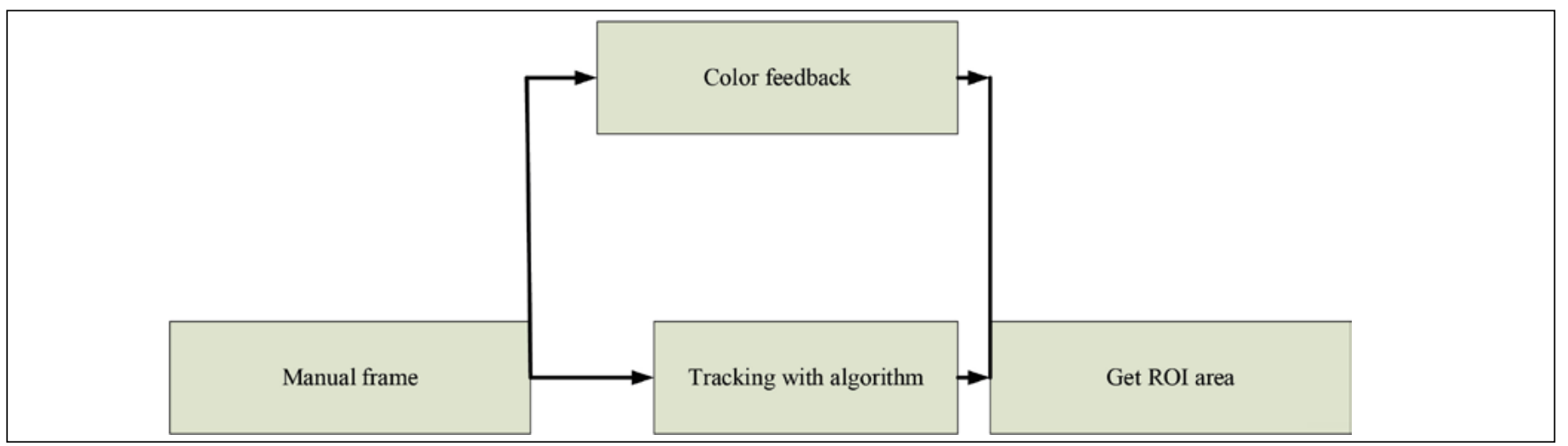

Figure 2. The main process of the algorithm.

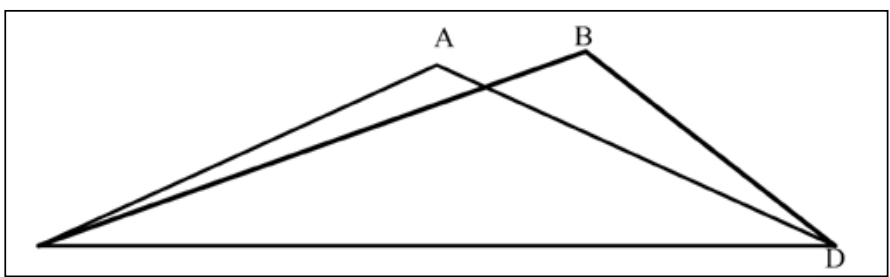

Figure 3. Center coordinate change diagram.

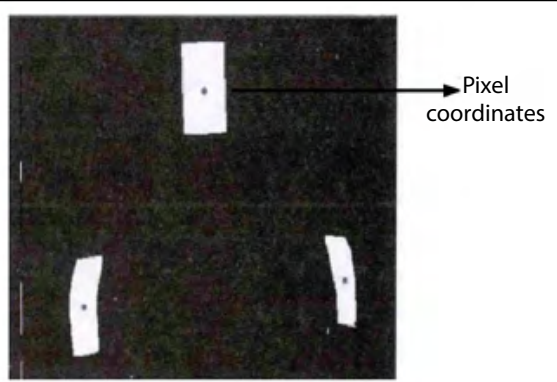

Figure 4. Detecting the coordinates of the center pixel.

The letters in the figure indicate the center point of the pixel block. When the athlete does not twist his head, the triangle ACD can detect 3 central pixels, and the pixel length can be calculated. The two edges with a relatively short distance are found, making difference between $A C$ and $A D$ and taking the absolute value. When the athlete twists his head, the coordinates of the black square of his hat will change with the coordinates of the next two blocks, and a new triangle BCD will be formed again. The difference between $B C$ and $B D$ is made with the same method, taking the absolute value. This value is not equal to 0 . Whether the athlete twists his head can be judged according to the ratio of this value to the $C D$ pixel value. In this research, the twist angle was set to 45 degrees. When the twist angle exceeds 45 degrees, the athlete is determined to twist his head once. It is assumed that the BCD triangle in the figure is formed when the athlete's twisting head angle is 45 degrees. The reality will be affected by many factors. Thus, this study expands the threshold value as an error. The equation for calculating the final threshold value $T$ is shown below.

$$
T=\frac{|E C-B D|}{C D} \times 110 \%
$$

\section{Biological-image processing based on MVEF}

In this research, a second-order derivative with a larger absolute value orthogonal to a straight line and a second-order derivative with a smaller absolute value along the line direction is used to represent a linear model. In the application of two-dimensional input images, a second-order partial derivative is used to construct a matrix with pixels $(i, y)$, and the second-order partial differential equation in four different directions are shown below.

$H=\left[\begin{array}{ll}f_{x x} & f_{x y} \\ f_{y x} & f_{y y}\end{array}\right]$
$f_{x x}=\frac{\partial^{2} f}{\partial x^{2}}=f(x-1, y)+f(x+1, y)-2 f(x, y)$
$f_{y y}=\frac{\partial^{2} f}{\partial y^{2}}=f(x, y-1)+f(x, y+1)-2 f(x, y)$
$f_{x y}=f_{y x} \frac{\partial^{2} f}{\partial_{x} \partial_{y}}=f(x+1, y+1)+f(x, y)$
$-f(x+1, y)-f(x, y+1)$

Where: The equation (7) represents the second-order partial differential in $f_{x x}$ direction. The equation (8) represents the second-order partial differential in $f_{x y}$ direction. The equation (9) and (10) represent the second-order partial differential in $f_{y x}$ and $f_{x y}$ directions. The properties of the second-order partial differential in the $x$ and $y$ directions are different from the other two directions, and the former is mixed. The main principle is to use the second-order information of the local structure of the image to extract the features of the image.

$\mathrm{H}$ is a real symmetric matrix and there exists a relation of $f_{x y}=f_{y x}$ . Therefore, the research applies two eigenvalues of the image, that is $\lambda_{1}$ and $\lambda_{2}$. Then they are used to enhance the filtering. The calculation equation of the eigenvalues is shown below.

$$
\lambda_{1}=k+\sqrt{k^{2}-Q^{2}}, \lambda_{2}=K-\sqrt{k^{2}-Q^{2}}
$$

$k=\left(f_{x x}+f_{y y}\right) / 2, Q=\sqrt{f_{x x} f_{y y}-f_{x y} f_{y x}}$

\section{RESULTS}

In this research, 30 table tennis enthusiasts are taken as the research object, and they are divided into different groups according to 
age. Children are recorded as group A. Adults are recorded as group B. Aged are recorded as group C. Among them, there are 15 men and 15 women, and they play table tennis freely for 5 minutes. The test results are shown in figure 5.

As can be seen from the figure 6 above, the 30 table tennis enthusiasts each turns their heads 39 times in the 5 minutes of exercise. According to the average table tennis player playing for one hour each time, each person plays a table tennis, and the total number of head turns is 468 times.

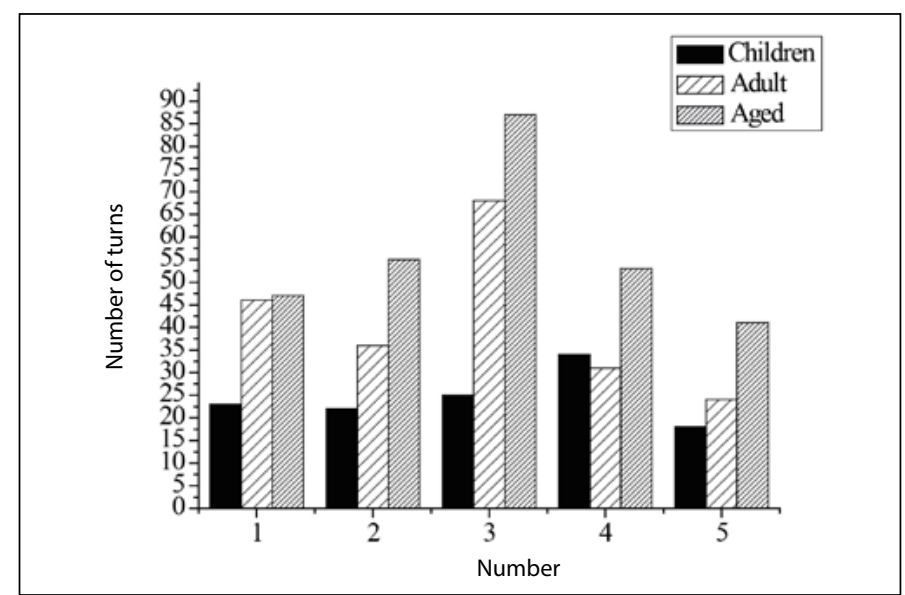

Figure 5. The number of head turns of men.

\section{DISCUSSION}

The detection of 30 table tennis enthusiasts with different ages and genders turning the head is performed. The result shows that the average number of head twists per person is 39 times. According to the average table tennis player playing for one hour each time, each person plays a table tennis, and the total number of head twists is 468 times. Among these three groups, the number of children turning the head is the least, and the number of aged is relatively high. It may be that the movement amplitudes of the aged are relatively large. Thus, the number of turning the head is more. It is closely related to the playing movement.

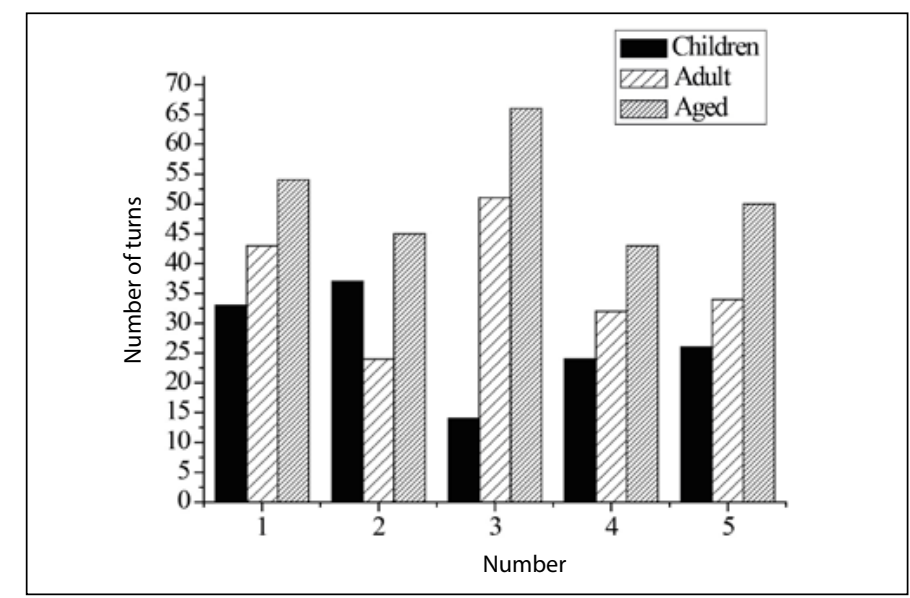

Figure 6 . The number of head turns of women.

After research, it is proved that the improved algorithm using color feedback has great feasibility and effectiveness. Proper exercise will reduce the incidence of cervical spine disease, promote blood circulation, and exercise neck muscles. Therefore, the probability of athletes suffering from cervical spine disease is very small.

\section{CONCLUSIONS}

In this study, the improved Camshift tracking algorithm for biological images is optimized and improved based on color feedback, and it is applied to the positioning and tracking of the $\mathrm{ROI}$ area in the set video and the center position of the image target. The results prove the superiority of the improved algorithm in this study. However, in the final experimental verification of this study, only table tennis enthusiasts were taken as the research object. Professional athletes should also be included in the experiment. Thus, the amateur and professional athletes can be compared, and the research results will be more comprehensive and in-depth.

All authors declare no potential conflict of interest related to this article

AUTHORS' CONTRIBUTIONS: Yang Lu collated all the experimental data. Chunmin Dai was a major contributor in writing the manuscript.

\section{REFERENCES}

1. Rani S. Designing of encryption algorithm based on visual cryptography and linear feedback shift register. Advanced Science Letters. 2018 [çited 2021 Jun 14];24(1):668-72. Availale from: https:// www.ingentaconnect.com/contentone/asp/asl/2018/00000024/00000001/art00194

2. Liu ZJ, Zeng XP, Li ZY, et al. Interference Alignment Algorithm Based on Feedback Concentration in D2D Communications. Wireless Personal Communications. 2017;95(5):1-15.

3. Fertig E J, Ozawa H, Thakar M, Howard JD, Krigsfel G, Favorov AV, et al. Abstract 777: The CoGAPS matrix factorization algorithm infers feedback mechanisms from therapeutic inhibition of EGFR that increases expression of growth factor receptors. Cancer Research. 2016 [çited 2021 Jun 14];76(14 Supplement):777-777. Availale from: https://cancerres.aacrjournals.org/content/76/14_Supplement/777

4. Ung WC, Funane T, Katura T, Sato H, Tang TB, Hani AFM, et al. Effectiveness Evaluation of Real-Time Scalp Signal Separating Algorithm on Near-Infrared Spectroscopy Neurofeedback. IEEE J Biomed Health Inform. 2018;22(4):1148-56.
5. Amano K. S9-3. Associative learning between orientation and color created by decoded fMRI neurofeedback. Clinical Neurophysiology. 2018;129(5):e26.

6. Kardan I, Akbarzadeh A. Output feedback assistive control of single-DOF SEA powered exoskeletons. Industrial Robot. 2017;44(3):275-87.

7. Verdoljak RD, Linderman LE. Sparse feedback structures for wireless control of civil systems. Struc Control Health Monit. 2015:9435.

8. Hasan S. Performance-aware architectures for parallel 4D color fMRI filtering algorithm: a complete performance indices package. IEEE Transactions on Parallel \& Distributed Systems. 2016;27(7):2116-29.

9. Ma S, Li Q, Zhang S. An adaptive closed-loop image dehazing algorithm based on the feedback mechanism. Dianzi Yu Xinxi Xuebao/Journal of Electronics \& Information Technology. 2016;38(2):400-7. 